\title{
Effect of Ethanol on ACC Synthase Activity and Gene Expression in Ripening Banana
}

\author{
MATsui Toshiyuki*1 and YoKozeKi Kyosuke*1
}

\author{
* 1 Department of Bioresource Production, Faculty of Agriculture, Kagawa University \\ 2393, Ikenobe, Miki-cho, Kita-gun, Kagawa 761-0795
}

\begin{abstract}
Postharvest application of $35 \sim 90 \%$ ethanol is reported to remove astringency and improve sweetness of banana. In order to determine the specific pattern and localization of gene expression, banana fruits were treated with $60 \%$ ethanol and control and then the total RNA extracted from the banana was hybridized with the RNA probe of ACC synthase gene. The highest ACC synthase activity was observed at 6 days after the ethanol treatment, while the accumulation of MA-ACS 1 mRNA (encoding banana ACC synthase during ripening) was observed in 9 days after the same treatment. In this experiment, the date of highest ethylene production coincided with the date of highest ACC synthase activity. The expression of ACC synthase gene is considered to occur firstly in pulp and then it occur in the peel on the basis of the signal intensity by Northern blot analysis.
\end{abstract}

(Received Dec. 18, 2002 ; Accepted Jun. 23, 2003)

In banana fruit, ethanol did not induce a rapid and immediate increase in respiration in contrast to ethylene ${ }^{1)}$. However, the respiratory peak of ethanoltreated fruits was observed earlier than that of the control fruits. Although ethylene is commercially used to ripen banana, postharvest application of 35 $\sim 90 \%$ ethanol is reported to remove astringency and improve sweetness ${ }^{2), 3)}$. The fruit ripening is related to respiratory behavior and ethylene production during the later stages of maturation. The biosynthetic pathway of ethylene in higher plants was well characterized and ACC synthase (EC 4.4.1.14) and ACC oxidase (EC 1.4.3) were identified. ACC synthase catalyzed the conversion of $S$-adenosylmethionine (SAM) to ACC and is regarded as the rate-limiting step $^{4}$.

Expression of ACC synthase gene has been investigated in many fruits, such as tomatoes ${ }^{5), 6)}$, apple $^{7}$, pumpkin $^{8)}$, banana ${ }^{9)}$ and so on. ACC synthase is known to be encoded by a multigene family ${ }^{10}$ and MA-ACS 1, ACS 2 and ACS 3 among the family were already investigated in ethylene treated banana9. The MA-ACS 1 and MA-ACS 2 mRNAs correlated with the ethylene production of ripening, wounding and sliced banana, respectively but the MA-ACS 3 showed low level of expression in banana9). There is no work relating ACC synthase gene expression with ethanol-treated banana and this prompted as to construct MA-ACS 1 probe and check the expression.

In order to determine the specific expression in $60 \%$ ethanol-treated and control banana, the total RNA was hybridized with the MA-ACS 1 mRNA probe which was synthesized from the banana cDNA of ACC synthase obtained from DDBJ database (AF $\left.080258^{11}\right)$.

\section{Materials and Methods}

\section{Plant materials}

Green 'Cavendish' bananas were purchased from a local wholesale market. The hands of banana were separated into individual fingers and distributed to $60 \%$ ethanol-treated and control groups. Each group was assigned to 3 jars. Six fingers (approximately $900 \mathrm{~g}$ ) per jar were kept in $6 \ell$ glass jars and sprayed with $10 \mathrm{~m} \ell$ of water (control) and $60 \%$ ethanol for $24 \mathrm{hr}$. The jars were immediately covered with perforated plastic film and were stored at $25^{\circ} \mathrm{C}$. Peel color was monitored daily and scored according to an index of 1 (green) to 8 (yellow, surface covered with large senescent spots $)^{12}$. After treatment, three samples were selected randomly in the jars after the elapse of 0 , $3,6,9$ and 12 days. The fruit was cut horizontally into 3 portions and the central portion was divided into peel and pulp. Five mm thick pulps

* 1 E-mail : MATsur Toshiyuki ; matsui@ag.kagawa-u.ac.jp, YOKOZEKI Kyosuke ; ykzkrinnesukillozveladot@jp-s.ne.jp 
and $2 \mathrm{~cm}$ peels were frozen with liquid nitrogen and stored at $-80^{\circ} \mathrm{C}$ until needed for RNA extraction.

\section{Measurement of respiration $\left(\mathrm{CO}_{2}\right)$ and ethylene production}

Each jar containing 12 fingers was kept sealed for $2 \mathrm{hr}$ at $25^{\circ} \mathrm{C} . \mathrm{CO}_{2}$ in the headspace of the jar was measured by a gas chromatograph (GC) equipped with thermal conductivity detector (Shimazu GC8 AIT).

From each treated-fruit before freezing with liquid nitrogen, $2 \mathrm{~g}$ of peel or pulp discs in capped test tube were incubated in a water bath shaker for 1 hr at $25^{\circ} \mathrm{C}$. After incubation, the capped tube was transferred in the ice bath and ethylene produced in the head space of the tube was determined by gas chromatograph. Ethylene gas was also analyzed using the same GC model fitted with a flame ionization detector (FID) and all measuring conditions were the same as the previous paper ${ }^{13)}$.

\section{ACC synthase and ACC oxidase activity assays}

Frozen tissue ( $2 \mathrm{~g}$ ) was added in liquid nitrogen and was ground in a cooled mortar and pestle with $4 \mathrm{~m} \ell$ of extraction buffer $(400 \mathrm{mM}$ K-phosphate $\mathrm{pH}$ 8.5, $10 \mu \mathrm{M}$ pyridoxal 5'-phosphate (PLP), $0.5 \%$ mercaptoethanol and $20 \%(\mathrm{~W} / \mathrm{V})$ glycerol). The resulting homogenate was filtered through 4 layers Kimwipe and the filtrate was charged on a dry Sephadex G-25 column (1.5 i.d. $\times 7 \mathrm{~cm})$ prepared by centrifuging at 3,000 r.p.m for 3 min at $4{ }^{\circ} \mathrm{C}$ just before use. The elute solution recentrifuged at the same condition was concentrated to $1 / 3$ of its original volume by polyethylene glycol 6,000. The solution ( $2 \mathrm{~m} \ell$ ) was applied to a Sephadex $G-25$ fine column (1.5 i.d. $\times 6 \mathrm{~cm}$ ) equilibrated with $10 \mathrm{mM}$ K-phosphate buffer ( $\mathrm{pH}$ 8.5). The elute solution was used for the enzyme assay, according to the method described by LIZADA and YANG ${ }^{14)}$. To $0.4 \mathrm{~m} \boldsymbol{l}$ of the elute solution, $0.2 \mathrm{~m} \ell$ of $50 \mathrm{mM}$ Hepes- $\mathrm{KOH}$ buffer containing $10 \mu \mathrm{M}$ PLP and $200 \mu \mathrm{M}$ SAM was added, and afterward it was incubated at $30^{\circ} \mathrm{C}$ for $15 \mathrm{~min}$, followed by mixing with $400 \mu$ of stopping reagent (Bleach-saturated $\mathrm{NaOH}(2: 1, \mathrm{~V} / \mathrm{V})$ and $10 \mathrm{mM}$ $\mathrm{HgCl}_{2}$ in the ratio of $\left.1: 3(\mathrm{~V} / \mathrm{V})\right)$. A blank experiment was carried out using ice bath instead of $30^{\circ} \mathrm{C}$ and the other conditions were the same described above. After immediately putting a stopper, the tube was shaken vigorously for $15 \mathrm{sec}$ and kept in the ice bath for 3 min. Ethylene produced in the head space $(1 \mathrm{~m} \ell)$ of capped tubes after $1 \mathrm{hr}$ incubation was determined by the same GC described above. The assay for ACC oxidase was made as in the previous paper ${ }^{15)}$.

\section{RNA extraction and cloning of ACC synthase and ACC oxidase genes}

The frozen tissue was pulverized to a fine powder with a mortar and pestle. Total RNA was extracted by the hot borate method ${ }^{16)}$. The total RNA was directly used for cDNA synthesis without the isolation of poly $(\mathrm{A})^{+}$RNA. To isolate ACC synthase fragments, degenerate oligonucleotide primers homologous to conserved regions of ACC synthase were synthesized. The degenerate oligonuclotide primers for PCR were synthesized to two amino acid domains conserved in bananas ACC synthase genes, for the sense primer ( $5^{\prime}$. CAACGCCWTATTAYCCGGGAT- $3^{\prime}$ ), and the antisense primer (5'-TGGCRAARCACACCCTGAACC $\left.-3^{\prime}\right)$, respectively. The first strand cDNAs, synthesized from $2 \mu \mathrm{g}$ of total RNA isolated from ethanol-treated fruits, were performed with a SuperScript $^{\mathrm{TM}}$ Preamplification System for First Strand cDNA (BRL, Tokyo, Japan) containing RT. The primers were amplified by PCR. The parameters for PCR were 30 cycles of heating at 94 ${ }^{\circ} \mathrm{C}$ for $45 \mathrm{~s}$, at $55^{\circ} \mathrm{C}$ for $30 \mathrm{~s}$ and at $72^{\circ} \mathrm{C}$ for $90 \mathrm{~s}$. The Sal I and Not I restriction site sequences were also included at the 5 ' -end of both sense and antisense primers, to facilitate cloning of PCR product. The PCR products were cloned into the pSPORT 1 vector (BRL, Tokyo, Japan). The cloning of ACC oxidase was performed in a similar manner as in the previous paper ${ }^{15)}$.

\section{Preparation of the digoxigenin (DIG) -UTP- labeled RNA probe}

The cloned RT-PCR product including the coding region of ACC synthase gene was cleaved by Not I and Sal I from the pSPORT 1 vector that had been amplified in Escherichia coli (DH- $5 \alpha)$ and it was purified by gel electrophoresis and recovered. Antisense DIG-labeled RNA probes were prepared using cloned RT-PCR product, and the DIG RNA Labeling kit (Boehringer Mannheim) according to the manufacturer's instruction. The RNA probe of ACC oxidase was produced in a similar manner as in the previous paper ${ }^{15)}$

\section{Northern blot hybridization}

Ten $\mu \mathrm{g}$ of total RNA was subjected to electrophoresis on a $1.0 \%$ agarose gel that contained $0.66 \mathrm{M}$ formaldehyde and transferred to 
Hybond- $\mathrm{N}^{+}$(Amersham) by capillary action with 20 $\times$ SSC, according to manufacturer's instruction. After drying the membrane, the RNAs were fixed with UV. The membrane was preincubated in $5 \times$ SSPE, $5 \times$ Denhart's solution and $0.5 \%$ SDS at 60 ${ }^{\circ} \mathrm{C}$ for $3 \mathrm{~h}$ and then probed with the gene-specific antisense DIG-labeled RNA probe at $60^{\circ} \mathrm{C}$ for $24 \mathrm{~h}$. The membrane was washed once with $2 \times$ SSPE containing $0.1 \%$ SDS for $10 \mathrm{~min}$ at room temperature, once with $1 \times \mathrm{SSPE}$ plus $0.1 \%$ SDS for $15 \mathrm{~min}$ at $65^{\circ} \mathrm{C}$ and twice with $0.2 \times \mathrm{SSPE}$ containing $0.1 \%$ SDS for $15 \mathrm{~min}$ each at $65^{\circ} \mathrm{C}$. After allowing sheep anti-DIG $\mathrm{Fab}^{17)}$ fragments conjugated to alkaline phosphatase to bind to the DIG-labeled probe, the excess antibody was removed. Signals were detected by color reaction using 5 -bromo- 4 chloro- 3 -indolylphosphate (BCIP) and nitro blue tetrazolium salt as the substrate. RNA samples were ensured by measuring UV spectro meter (UV1200, Shimazu, Japan) and hybridizing an internal control gene, banana actin cDNA. In the case of ACC oxidase, the procedure for Northern blot hybridization was made as in the previous paper ${ }^{15}$.
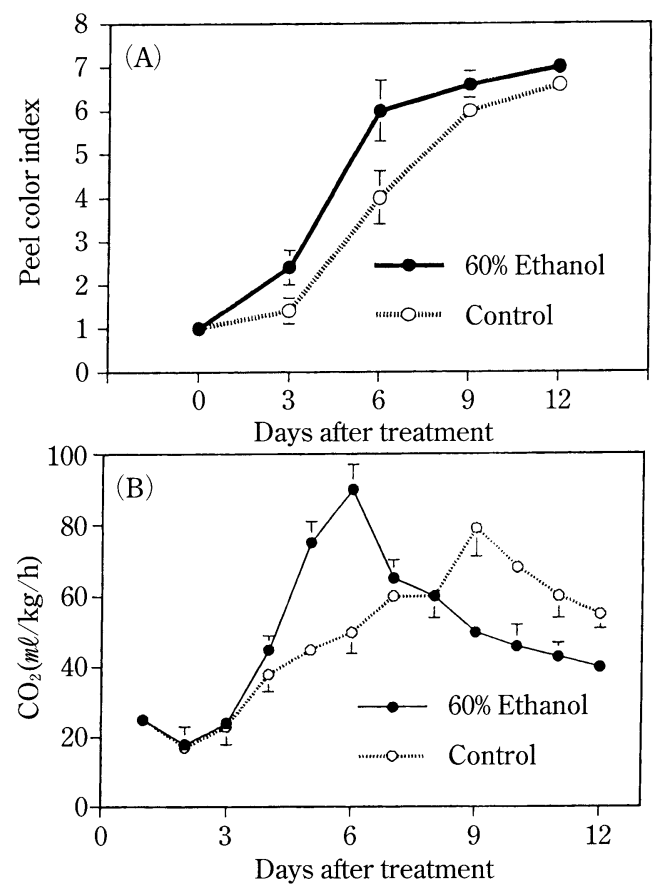

Fig. 1 Changes in peel color development (A) and respiration rate $(\mathrm{B})$ of ethanol-treated banana fruits stored at $25^{\circ} \mathrm{C}$

Each point represents the mean of 3 replicates.

Vertical bars indicate the standard error when larger than symbol.

\section{Results and Discussion}

\section{Changes in peel color development, respiration rate and ethylene production}

Fig. 1 (A) shows the peel color development in the $60 \%$ ethanol-treated and control bananas. The development of the yellow color of the peel was hastened by the application of $60 \%$ ethanol. Ripening of the fruit to color stage 5 (yellow with green tips) took about 7 or 8 days in control fruits, and 5 or 6 days in $60 \%$ ethanol-treated fruits. The fruits ripeness in this experiment reached $2 \sim 3$ days faster than the previous paper ${ }^{15)}$.

Ethanol-treated banana after harvest showed more uniform ripening ${ }^{18)}$ (means consistent sugar, organic acid contents and color) than control banana, whereas ethylene-treated banana was superior to the ethanol-treated banana in relation to the uniform ripening ${ }^{18)}$.

The climacteric maximum corresponding to respiration maximum was observed at 9 and 6 days after treatment in control and $60 \%$ ethanoltreated fruits, respectively (Fig. 1 (B)).

Fig. 2 shows ethylene production in the peel and

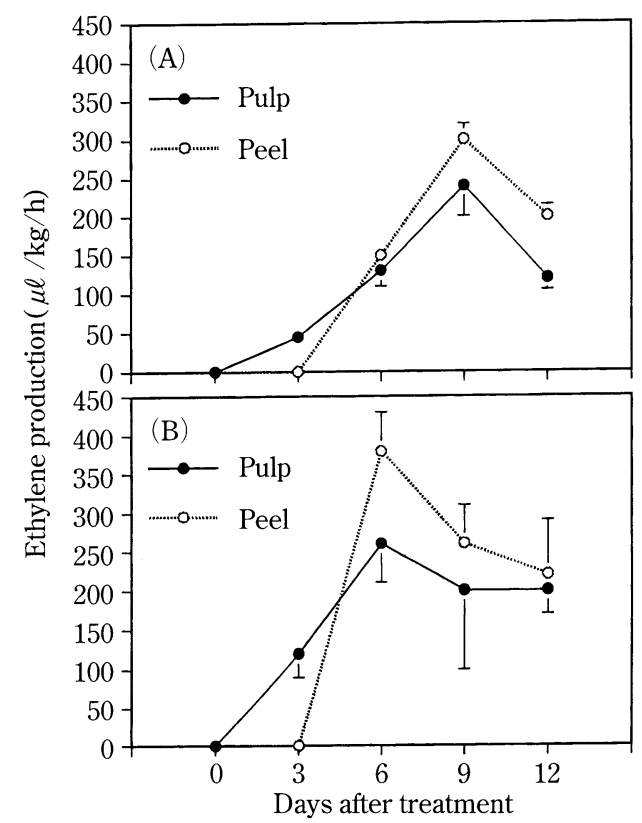

Fig. 2 Changes in the level of ethylene production in control (A) and $60 \%$ ethanol-treated banana (B) fruits stored at $25^{\circ} \mathrm{C}$

Each point represents the mean of 3 replicates.

Vertical bars indicate the standard error when larger than symbol. 
pulp of ethanol-treated and control bananas. The highest ethylene production of control and 60\% ethanol-treated fruit was at 9 and 6 days, respectively. In ethanol-treated and control fruits, the ethylene showed higher production in peel than that in pulp.

The climacteric maximum (Fig. 1(B)) was the same day of the highest ethylene production in the $60 \%$ ethanol-treated (Fig.2 (B)) and the control fruit (Fig. 2 (A)), respectively. The climacteric maximum in the ethanol-treated fruit was accelerated by 1 day in comparison with the previous paper ${ }^{15)}$ since the higher ethylene production was caused by the faster ripening.

\section{Changes in ACC synthase and ACC oxidase}

Figs. 3 and 4 show changes in ACC synthase

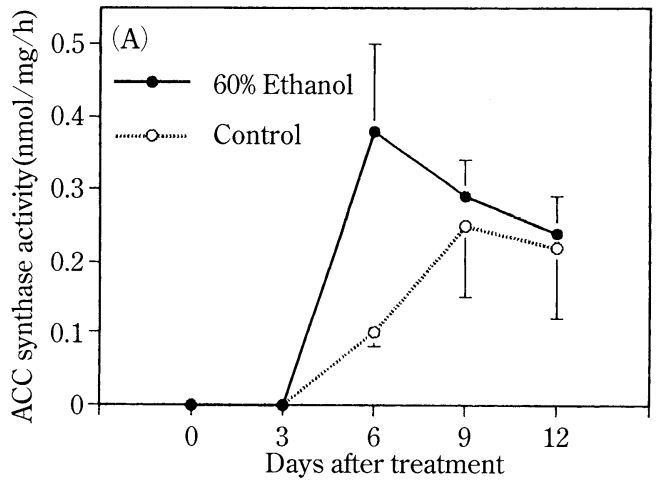

(B)

(C)
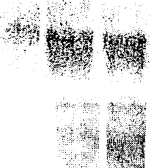

(D)

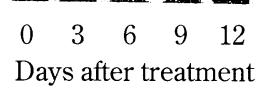

$\left(\mathrm{B}^{\prime}\right)$

$\left(C^{\prime}\right)$

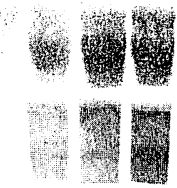

$\left(D^{\prime}\right)$

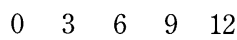

Days after treatment
Fig. 3 Changes in ACC synthase activity (A) in pulp and its expression in Northern blot analysis on ethanol-treated (B) and control (C) banana peel and pulp stored at $25^{\circ} \mathrm{C}$

(A) : ACC synthase activities of banana pulp. Each point represents the mean of 3 replicates. Vertical bars indicate the standard error when larger than symbol. ACC synthase acitivities of banana peel could not be measured due to the existence of disturbing substances.

(B), ( $\left.\mathrm{B}^{\prime}\right)$ : Expression of ACC synthase genes in ethanol-treated banana fruits, peel and pulp, respectively.

(C), $\left(\mathrm{C}^{\prime}\right)$ : Expression of ACC synthase genes in control banana fruits, peel and pulp, respectively.

(D), ( $\left.\mathrm{D}^{\prime}\right)$ : Expression of Actin genes in ethanol-treated banana fruits, peel and pulp, respectively. (Data not shown in control) Each lane contained $10 \mu \mathrm{g}$ total RNA. Blots were hybridized with DIG labeled MA-ACS 1 mRNA probe. MAactin was used as internal standard of the blot intensity. and ACC oxidase activities of pulp (A) and their expressions in Northern blot analysis on ethanoltreated $\left(\mathrm{B}, \mathrm{B}^{\prime}\right)$ and control peel $(\mathrm{C})$ and pulp $\left(C^{\prime}\right)$ of banana fruits, respectively. The ACC synthase activity of ethanol-treated pulp was observed between 3 and 6 days after treatment and peaked on 6 days, whereas the maximum activity of control pulp was observed at 3 days behind the maximum peak of the ethanol-treated pulp. Due to existence of disturbing substances in the peel, the enzyme activity was not calculated in the peel for both treatments. As the ethylene production was observed in the peel for both treatments, ACC synthase is considered to be present in the peel. The highest ACC synthase activity in the pulp was observed at 9 and 6

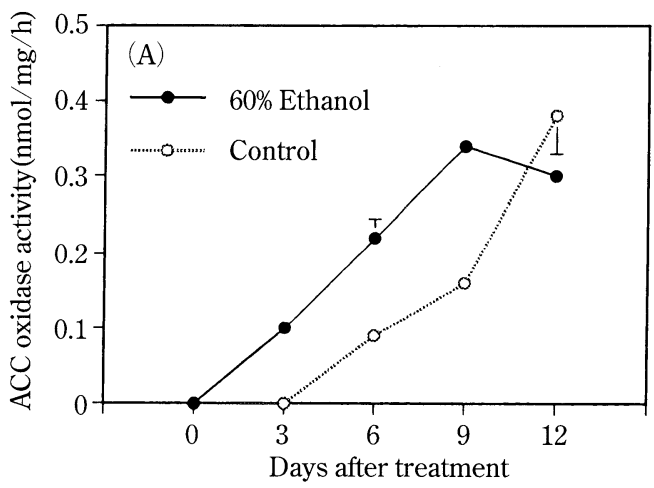

(B)

(C)

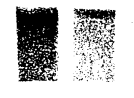

(B')

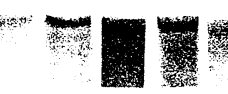

$\left(C^{\prime}\right)$

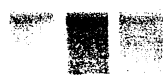

(D) $=$

$\begin{array}{lllll}0 & 3 & 6 & 9 & 12\end{array}$

Days after treatment

D')

$\begin{array}{lllll}0 & 3 & 6 & 9 & 12\end{array}$

Days after treatment

Fig. 4 Changes in ACC oxidase activity (A) in pulp and its expression in Northern blot analysis on ethanol-treated

(B) and control (C) banana peel and pulp stored at $25^{\circ} \mathrm{C}$

(A) : ACC oxidase activities of banana pulp. Each point represents the mean of 3 replicates. Vertical bars indicate the standerd error when larger than symbol. ACC oxidase activities of banana peel could not be measured due to the existence of disturbing substances.

(B), (B') : Expression of ACC oxidase genes in ethanol-treated banana fruits, peel and pulp, respectively.

(C), $\left(\mathrm{C}^{\prime}\right)$ : Expression of ACC oxidase genes in control banana fruits, peel and pulp, respectively.

(D), ( $\left.\mathrm{D}^{\prime}\right)$ : Expression of Actin genes in ethanol-treated banana fruits, peel and pulp, respectively. (Data not shown in control) Each lane contained $10 \mu \mathrm{g}$ total RNA. Blots were hybridized with DIG labeled $M A-A C O 1$ mRNA probe. MAactin was used as internal standard of the blot intensity. 
days after treatment in control and 60\% ethanoltreated fruits, respectively and it coincided with the highest ethylene production.

As shown in Fig. 4, the highest ACC oxidase activity in the ethanol treated pulp was observed at 9 days after treatment. The highest ACC synthase activity appeared ahead of the highest ACC oxidase activity.

\section{Expression of ACC sythase and ACC oxidase genes}

The behavior of ACC synthase activity in the pulp (Fig.3 (A)) paralleled that of the ethylene production in control (Fig. $2(\mathrm{~A}))$ and $60 \%$ ethanoltreated pulp (Fig. 2 (B)). The accmulation of MA-ACS 1 mRNA in the ethanol-treated pulp showed an increasing trend until 9 days and declined in 12 days, whereas that in control reached a high level in 12 days. The MA-ACS 1 gene showed higher message level in the ethanol-treated than control. The same trend was observed in the peel but the accumulation of $M A-A C S$ level was lower than the pulp. The accumulation of MA-ACS 1 mRNA in the ethanol-treated pulp was observed ahead of that in the peel, whereas that of MA-ACO 1 mRNA (Fig. 4 (B')) was hastened earlier 3 days than that of $M A$ -ACS 1 mRNA. Similar observation that ACC oxidase gene showed faster expression than ACC synthase gene had been already reported by LIU, et $a l .^{9)}$ on the basis of Northern blot analysis. The ethylene production requires both ACC synthase and oxidase, especially the synthase is regarding as the ratelimiting enzyme ${ }^{4)}$.

According to LIU et al. ${ }^{9}$, , only $M A-A C S 1$ mRNA was detected in ripening banana. MA-ACS $1 \mathrm{mRNA}$ coincided with ACC synthase activity in the ethylene-treated banana. Among the members of $M A$ -ACS multigene family, MA-ACS 2 mRNA was reported to be induced by wounding banana, whereas the transcript of MA-ACS 3 mRNA was reported to be undetected by Northern analysis". Therefore, MA-ACS 2 and MA-ACS 3 mRNA are considered not to coincide with ACC synthase activity in our report. However, the problem that the expression of $M A-A C S 1 \mathrm{mRNA}$ did not parallel ACC synthase activity is unknown at this time.

After all, we found that the highest accumulation date of $M A$-ACS 1 mRNA was observed at 9 days when the highest ACC synthase activity was observed at 6 days after the ethanol treatment. The expression of ACC synthase gene is considered to occur firstly in pulp and then it occur in the peel on the basis of Northern blot results.

\section{Reference}

1 ) Agravante, J. U., Matsui, T. and Kitagawa, H.: Changes in pectin methylesterase, polygalacturonase and pectic substances of ethylene- and ethanoltreated bananas during ripening, J. Jpn. Soc. Food Sci. Technol., 38, 527 532 (1991)

2 ) HoriBe, K. : The method of removal of astoringency in banana (1), Jpn. Tokkyo Koho., 52, 37057 (1979)

3 ) Horibe, K. : The method of removal of astoringency in banana (2), Jpn. Tokkyo Koho., 56, 33055 (1981)

$4)$ YAng, S. F. and Hoffman, N. E.: Ethylene biosynthesis and its regulation in higher plants, Annu. Rev. Plant Physiol., 35, 155 189 (1984)

5 ) Olson, D. C., White, J. A, Edelman, L., Harkin S, R. N. and Kende, H.: Differential expression of two genes for 1-aminocyclopropane-1-carboxylate synthase in tomato fruits, Pro. Natl. Acad. Sci. USA, 88, 5340 5344 (1991)

6 ) Lincoln, J. E., Campbell, A. D., Oetiker,J., Rottmann, W. H., Oeller, P. W., Shen, N. F. and Theologis, A.: LE-ACS 4, a fruit ripening and wound-induced 1-aminocyclopropane-1-carboxylate synthase gene of tomato, J. Biol. Chem., 268, 19422 〜19430 (1993)

7 ) YIP,W. K., Dong, H. G. and YONG, S. F. : Purification and characterization of 1 aminocyclopropane-1-carboxylate synthase from apple fruits, Plant Physiol., 95, 251 257 (1991)

8 ) Sato, T., Oeller, P. W. and Theologis, A.: The 1 -aminocyclopropane- 1 -carboxylate synthase of cucuribita, J. Biol. Chem., 266, 3752 3759 (1991)

9 ) Liu, X., Siomi, S., Kubo, Y., Nakamura, R. and INABA, A. : Characterization of ethylene biosynthesis associated with ripening in banana fruit, Plant Physiol., 121, 1257 (1999)

10) Thelogis, A.: One rotten apple spoils the whole bushel: the role of ethylene in fruit ripening, Cell, 70, 181 184 (1992)

11) Liv, P., GoH, C. J., LoH, C. S. and PuA, E. A.: Unpublished Data from DDBJ Database, Accession No. AF080258 (1998)

12) Customer Services Department, Chiquita Brands Inc.: Color Preferences Chart, pp. 2 (1975)

13) Matsui, T.: Maturity evaluation of kiwifruit determined on the basis of sugar and acid contents and $\mathrm{CO}_{2}$ and $\mathrm{C}_{2} \mathrm{H}_{4}$ production rates, Tech. Bull. Fac. Agri, Kagawa Univ., 45, 11 16 
(1993)

14) Lizada, M. C. C. and YAnG, S. F.: A simple and sensitive assay for 1 -aminocyclopropane- 1 carboxylic acid, Anal. Biochem., 100, 140 145 (1979)

15) Matsui, T. and Kosugi, Y.: Expression of Accoxidase gene in ethanol-treated banana fruit, Food Preservation Sci., 28, 317 321 (2002)

16) WAn, C-Y. and Wilkins, T. A.: A modified hot borate method significantly enhance the yield of high-quality RNA from cotton, Anal. Biochem., 223, $7 \sim 12$ (1994)

17) King, R. C. and Stansfield, W. D.: A dictionary of genetics (Oxford University Press, Oxford), p. 112 (1990)

18) Agravante, J. U: Studies on physiological and biochemical changes during ripening of 'cavendish' banana, Ehime United Graduate School Agricultural Science (Ehime University, Japan; PhD Thesis), p. 114 (1991)

\section{追熟バナナ果実のACC合成酵素活性と 遺伝子発現におけるエタノールの効果}

\author{
松井年行 ${ }^{* 1} \cdot$ 横関恭輔*1 \\ * 1 香川大学農学部生物生産学科 \\ （テ761-0795 香川県木田郡三木町池戸2393）
}

収穫後に35～90\%のエタノールでバナナ果実を処理す ると渋味の除去と甘味の増すことが報告されている。遺 伝子発現の特異的なパターンと局在を調べるために, バ ナナ果実を $60 \%$ エタノール処理とコントロール処理し, ついでバナナから抽出された全RNAをACC合成酵素遺 伝子のプローブとハイブリダイゼイションさせた。

最も高いACC合成酵素活性は, エ夕ノール処理後 6 日目に観察され, 一方MA-ACS 1 のmRNA (バナナのACC 合成酵素遺伝子をコードしている）は同様の処理後 9 日 目であった。本報告で, 最も高いエチレン生成日は最も 高いACC合成酵素活性日に一致していた。

ノーザン分析のシグナル強度に基づくとACC合成酵 素遺伝子の発現がはじめに果肉で起こり，ついで果皮で 起こると考えられる。

(平成14年12月18日受付, 平成15年 6 月 23 日受理) 